\title{
ANTIBIÓTICOS: IMPORTÂNCIA TERAPÊUTICA E PERSPECTIVAS PARA A DESCOBERTA E DESENVOLVIMENTO DE NOVOS AGENTES
}

\author{
Denise Oliveira Guimarães, Luciano da Silva Momesso e Mônica Tallarico Pupo* \\ Departamento de Ciências Farmacêuticas, Faculdade de Ciências Farmacêuticas de Ribeirão Preto, Universidade de São Paulo, \\ Av. do Café, s/n, 14040-903 Ribeirão Preto - SP, Brasil
}

Recebido em 26/2/09; aceito em 21/8/09; publicado na web em 24/2/10

\begin{abstract}
ANTIBIOTICS: THERAPEUTIC IMPORTANCE AND PERSPECTIVES FOR THE DISCOVERY AND DEVELOPMENT OF NEW AGENTS. There is a continuous need for antibiotics, mainly with new mechanisms of action, since infectious diseases represent the second major cause of death in the world and bacteria resistance levels are high. This review describes the contribution of microbial natural products for the development of the major antibiotic classes, the mechanisms of action of current antibiotics, some modern approaches involving genetic tools for the discovery and development of new antibiotics from microbial products and antibiotics in clinical trials.
\end{abstract}

Keywords: microbial natural products; drug discovery; antibiotics.

\section{INTRODUÇÃO}

Antibióticos são compostos naturais ou sintéticos capazes de inibir o crescimento ou causar a morte de fungos ou bactérias. Podem ser classificados como bactericidas, quando causam a morte da bactéria, ou bacteriostáticos, quando promovem a inibição do crescimento microbiano. ${ }^{1}$

As bactérias são organismos unicelulares, identificados pela primeira vez por van Leeuwenhoek por volta dos anos 1670, após a invenção do microscópio. Porém, somente no século XIX a possibilidade destes micro-organismos serem causadores de processos infecciosos começou a ser aventada. Esta hipótese surgiu após os elegantes experimentos de Louis Pasteur, que demonstrou que algumas linhagens de bactérias eram importantes para processos de fermentação e, também, que as bactérias eram de ampla distribuição pelo meio ambiente. ${ }^{2}$ Após a segunda metade do século XIX, cientistas como Robert Koch identificaram micro-organismos responsáveis por doenças como tuberculose, cólera e febre tifoide. Nessa época, as pesquisas eram conduzidas na busca de agentes químicos que apresentassem atividade antibiótica. O pesquisador Paul Ehrlich, conhecido como o pai da quimioterapia - uso de substâncias químicas contra infecções - foi responsável pelos conceitos primários de que uma substância química poderia interferir com a proliferação de micro-organismos, em concentrações toleráveis pelo hospedeiro. ${ }^{2}$ Em 1910, Ehrlich desenvolveu o primeiro antibiótico de origem sintética, salvarsan (1), usado contra sífilis. Poucos progressos foram conseguidos nos 20 anos seguintes para o desenvolvimento de antibióticos, até a introdução da proflavina (2), em 1934, agente amplamente utilizado na Segunda Guerra Mundial, principalmente contra infecções de feridas profundas. Entretanto, este composto era muito tóxico para ser usado em infecções bacterianas sistêmicas, o que evidenciava a necessidade de agentes mais eficazes. ${ }^{2} \mathrm{Em} 1935$, um marco na quimioterapia antibacteriana ocorreu com a descoberta de Gerhard Domagk de que o corante vermelho prontosil (3) apresentava atividade in vivo contra infecções causadas por espécies de Streptococcus. O prontosil (3) é um pró-farmaco que originou uma nova classe de antibióticos sintéticos, as sulfas ou sulfonamidas (22), que constituem a primeira classe de agentes efetivos contra infecções

*e-mail: mtpupo@fcfrp.usp.br sistêmicas introduzida no início dos anos $1940 .{ }^{2}$ Entretanto, as sulfas apresentam espectro de ação limitado e são pouco usadas atualmente.

Apesar destes avanços, o grande marco no tratamento das infecções bacterianas ocorreu com a descoberta da penicilina (4), por Alexander Fleming, em 1928. ${ }^{3} \mathrm{~A}$ atividade da penicilina era superior à das sulfas e a demonstração que fungos produziam substâncias capazes de controlar a proliferação bacteriana motivou uma nova frente de pesquisas na busca de antibióticos: a prospecção em culturas de micro-organismos, especialmente fungos e actinobactérias.

A penicilina G, ou benzilpenicilina (4), foi descrita em 1929 como agente antibiótico, porém somente foi introduzida como agente terapêutico nos anos 1940. Após o processo de industrialização da penicilina, especialmente em consequência da Segunda Guerra Mundial, ${ }^{4}$ foi observado um rápido crescimento na descoberta e desenvolvimento de novos antibióticos.

Entre os anos 1940-1960 vários antibióticos foram descobertos através de triagens de produtos naturais microbianos, sendo a maioria deles eficazes para o tratamento de bactérias Gram positivo: $\beta$-lactâmicos (5, cefalosporina), aminoglicosídeos (9, estreptomicina), tetraciclinas (12, clortetraciclina), macrolídeos (10, eritromicina), peptídeos (15, vancomicina) e outros (11 cloranfenicol, 16 rifamicina B, 14 clindamicina e polimixina B). Neste período apenas três derivados sintéticos foram introduzidos no mercado: isoniazida, trimetropim (23) e metronidazol. ${ }^{5}$

Entre os anos 1960-1980 foram introduzidos no mercado antibióticos semi-sintéticos eficazes para o tratamento de patógenos Gram positivo e Gram negativo, análogos aos antibióticos naturais já existentes. A maioria deles foi obtida a partir de protótipos naturais microbianos, como derivados $\beta$-lactâmicos (análogos de penicilina e cefalosporina, ácido clavulânico, aztreonam), análogos da tetraciclina, derivados aminoglicosídicos (gentamicina, tobramicina, amicacina). ${ }^{5}$

Entre os anos 1980-2000 as principais ferramentas utilizadas para a busca de novos antibióticos foram a genômica e as triagens de coleções de compostos, em detrimento às triagens de produtos naturais microbianos. Porém, houve uma redução dramática na identificação de novos protótipos antibióticos, ao mesmo tempo em que ocorreu um aumento na incidência de resistência bacteriana. Este período é marcado pela modificação do mercado de antibióticos pela introdução da classe das fluoroquinolonas sintéticas $(\mathbf{2 5 , 2 6})$ na metade dos anos 1980, desenvolvidas a partir do ácido nalidíxico (24). Alguns antibióticos baseados em 
protótipos naturais, como imipenem (derivado $\beta$-lactâmico) e análogos da eritromicina (10, derivado macrolídeo) também foram introduzidos neste período. A combinação de dois derivados semi-sintéticos de produtos naturais microbianos, quinupristina (18) e dalfopristina (19), foi aprovada para uso em infecções causadas por Enterococcus faecium resistente à vancomicina em 1999 pelo FDA (Food and Drug Administration). ${ }^{6}$

A partir de 2000, poucos antibióticos foram introduzidos para a terapêutica antimicrobiana. Em 2001, apenas um antibiótico de origem<smiles>Nc1cc(C=Cc2ccc(O)c(N)c2)ccc1O</smiles>

1 salvarsan<smiles>Nc1ccc2cc3ccc(N)cc3nc2c1</smiles>

2 prolavina<smiles>Nc1ccc(N=Nc2ccc(S(N)(=O)=O)cc2)c(N)c1</smiles>

3 prontosil<smiles></smiles><smiles>COc1cc(Cc2cnc(N)nc2N)cc(OC)c1OC</smiles>

23 trimetropim<smiles>CCn1cc(C(=O)O)c(=O)c2ccc(C)nc21</smiles>

24 ácido nalidíxico<smiles>CCn1cc(C(=O)O)c(=O)c2cc(F)c(N3CCNCC3)nc21</smiles>

25 enoxacina<smiles>O=C(O)c1cn(C2CC2)c2cc(N3CCNCC3)c(F)cc2c1=O</smiles>

26 ciprofloxacina

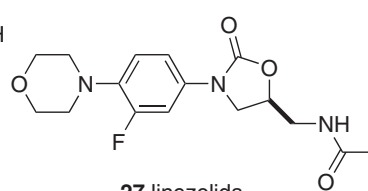

27 linezolida

Figura 1. Antibióticos de origem sintética

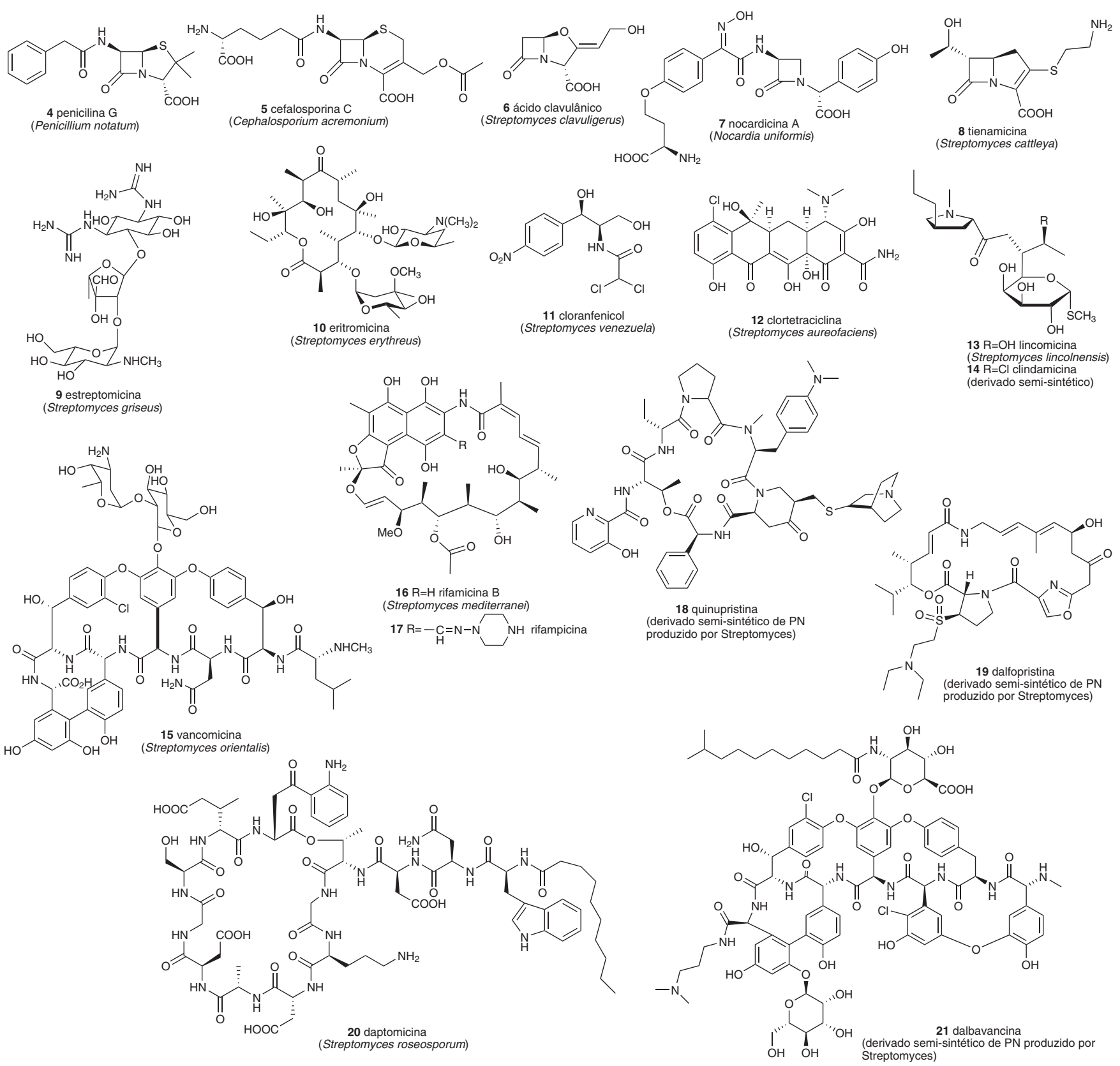

Figura 2. Fármacos representativos das principais classes de antibióticos de origem natural 
sintética da classe das oxazolidinonas foi introduzido no mercado farmacêutico, a linezolida (27). ${ }^{5}$ Os programas de descoberta de antibióticos de fontes naturais têm sido retomados em algumas indústrias farmacêuticas, levando à aprovação do lipodepsipeptídeo natural daptomicina (20) pelo FDA em 2003. O derivado semi-sintético glicopeptídico dalbavancina (21) encontra-se em fase III de triagens clínicas pelo FDA.,

\section{PRINCIPAIS CLASSES DE ANTIBIÓTICOS EM USO CLÍNICO}

Os antibióticos de origem natural e seus derivados semi-sintéticos compreendem a maioria dos antibióticos em uso clínico e podem ser classificados em $\beta$-lactâmicos (penicilinas, cefalosporinas, carbapeninas, oxapeninas e monobactamas), tetraciclinas, aminoglicosídeos, macrolídeos, peptídicos cíclicos (glicopeptídeos, lipodepsipeptídeos), estreptograminas, entre outros (lincosamidas, cloranfenicol, rifamicinas etc). Os antibióticos de origem sintética são classificados em sulfonamidas, fluoroquinolonas e oxazolidinonas. ${ }^{2,7,8}$ Os principais mecanismos de ação antibiótica destes agentes terapêuticos estão listados na Tabela 1.

\section{Antibióticos $\beta$-lactâmicos}

Os antibióticos $\beta$-lactâmicos corresponderam a 50\% do total de vendas de antibióticos em 2004. ${ }^{9}$ São agentes antibacterianos que inibem irreversivelmente a enzima transpetidase, que catalisa a reação de transpeptidação entre as cadeias de peptideoglicana da parede celular bacteriana. ${ }^{1,10} \mathrm{~A}$ atividade desta enzima leva à formação de ligações cruzadas entre as cadeias peptídicas da estrutura peptideoglicana, que conferem à parede celular uma estrutura rígida importante para a proteção da célula bacteriana contra as variações osmóticas do meio. Constituem a primeira classe de derivados de produtos naturais utilizados no tratamento terapêutico de infecções bacterianas. Hoje, várias décadas após a descoberta da penicilina, este grupo ainda contém os agentes mais comumente utilizados. Possuem amplo espectro de atividade antibacteriana, eficácia clínica e excelente perfil de segurança, uma vez que atuam na enzima transpeptidase, única em bactérias.

Todos os antibióticos $\beta$-lactâmicos têm um elemento estrutural farmacofórico em comum, o anel azetidinona de quatro membros, ou anel $\beta$-lactâmico. Na maioria dos antibióticos, o anel central $\beta$-lactâmico é fundido a outro anel de cinco (tiazolidínico) ou seis (dihidrotiazínico) membros, formando as penicilinas ou cefalosporinas, respectivamente. ${ }^{9,10} \mathrm{Em}$ geral, o sistema bicíclico é fundamental para a atividade destes antibióticos, por mimetizar o resíduo dipeptídico terminal D-Ala-D-Ala da cadeia de peptideoglicana, substrato da enzima transpeptidase (Figura 3).

O sistema bicíclico tensionado destes antibióticos contribui para o aumento da instabilidade química do anel $\beta$-lactâmico, altamente suscetível ao ataque de nucleófilos que promovem a hidrólise do grupo farmacofórico. No caso das penicilinas, o oxigênio da cadeia lateral acílica participa como nucleófilo em reação intramolecular que promove a abertura do anel $\beta$-lactâmico em meio ácido, inativando o antibiótico e inviabilizando sua administração por via oral (Figura 4A).

As modificações estruturais possíveis ficam restritas às cadeias laterais, que podem modular: a estabilidade em meio ácido, fundamental para a atividade por via oral destes fármacos; a estabilidade frente às $\beta$-lactamases, enzimas bacterianas relacionadas à resistência, que hidrolisam o grupo farmacofórico destes antibióticos e, o espectro de ação frente a bactérias Gram negativo.

Para aumentar a estabilidade em meio ácido foram adicionados grupos retiradores de elétrons no carbono $\alpha$ ao carbono carbonílico da cadeia lateral em penicilinas semi-sintéticas (ampicilina, amoxicilina, oxacilinas), que diminuem a nucleofilicidade do oxigênio carbonílico (Tabela 2).

O principal mecanismo de resistência bacteriana aos antibióticos $\beta$-lactâmicos é através da produção de enzimas que apresentam grupos nucleofílicos (em geral, resíduos de serina) capazes de promover a abertura do anel $\beta$-lactâmico. Neste caso, a modificação molecular responsável pelo aumento de resistência às $\beta$-lactamases foi a introdução de grupamentos volumosos no carbono $\alpha$ ao carbono carbonílico da cadeia lateral em penicilinas semi-sintéticas (meticilina, oxacilinas), que impedem o acesso dos antibióticos ao sítio ativo da enzima $\beta$-lactamase por impedimento estérico. ${ }^{10}$

Devido à natureza mais complexa da parede celular, as bactérias Gram negativo são mais resistentes à ação de antibióticos, que não são capazes de cruzar efetivamente esta barreira lipídica. Para ter acesso à célula bacteriana, os antibióticos devem cruzar a parede

Tabela 1. Principais mecanismos de ação antibiótica ${ }^{1,2}$

\begin{tabular}{|c|c|c|}
\hline Antibióticos & Alvo & Mecanismo de ação \\
\hline $\begin{array}{l}\beta \text {-lactâmicos (penicilinas, cefalosporinas, } \\
\text { carbapeninas, monobactamas) }\end{array}$ & Enzima transpeptidase & $\begin{array}{l}\text { Inibição da formação de ligação cruzada entre cadeias de } \\
\text { peptideoglicano, impedindo a formação correta da parede } \\
\text { celular bacteriana. }\end{array}$ \\
\hline$\beta$-lactâmicos (oxapeninas, sulfoxapeninas) & Enzima $\beta$-lactamase & $\begin{array}{l}\text { Inibição da enzima de resistência bacteriana, que degrada } \\
\text { antibióticos } \beta \text {-lactâmicos. }\end{array}$ \\
\hline Macrolídeos, lincosamidas, estreptograminas & Subunidade $50 \mathrm{~S}$ ribossômica & Inibição da síntese proteica bacteriana. \\
\hline
\end{tabular}

(dalfopristina e quinupristina), cloranfenicol, oxazolidinonas (linezolida)

Aminoglicosídeos, tetraciclinas

Glicopeptídeos (vancomicina, teicoplanina)

Peptídeos não ribossomais (bacitracina, gramicidina $\mathrm{C}$, polimixina $\mathrm{B}$ )

Lipodepsipeptídeos (daptomicina)

Membrana plasmática

Rifampicina

Fluoroquinolonas

Sulfonamidas
RNA polimerase dependente de DNA

Enzima DNA girase

Enzima di-hidropteroato sintetase
Inibição da síntese proteica bacteriana.

Complexação com as cadeias peptídicas não ligadas e bloqueio da transpeptidação, impedindo a formação correta da parede celular bacteriana.

Afetam permeabilidade da membrana bacteriana por facilitarem o movimento descontrolado de íons através da membrana.

Afeta permeabilidade da membrana bacteriana e bloqueia síntese de ácido pipoteicoico, componente da membrana externa de bactérias Gram positivo.

Inibição da síntese de RNA.

Bloqueio da replicação e reparo do DNA.

Bloqueio da formação de cofatores do ácido fólico, importantes para síntese de ácidos nucleicos. 
a) Mecanismo catalisado pela transpeptidase para a formação da ligação cruzada entre cadeias peptídicas

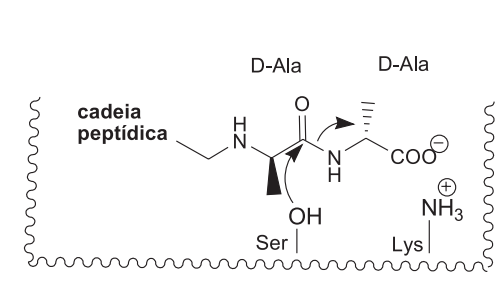

TRANSPEPTIDASE

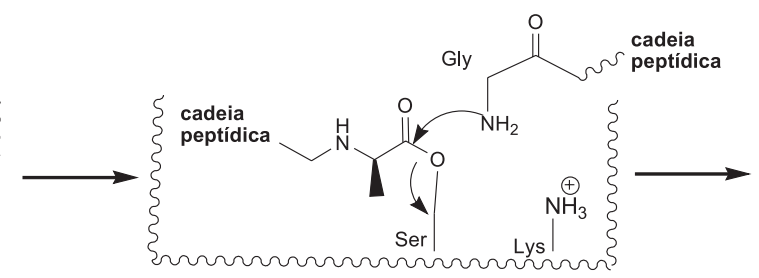

TRANSPEPTIDASE

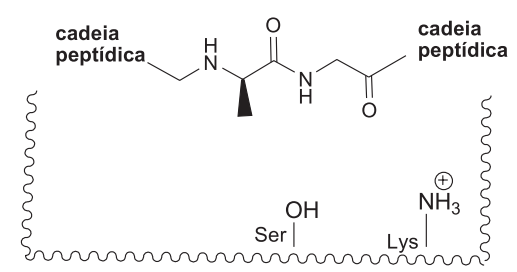

TRANSPEPTIDASE

b) Inibição irreversível da transpeptidase pelas penicilinas

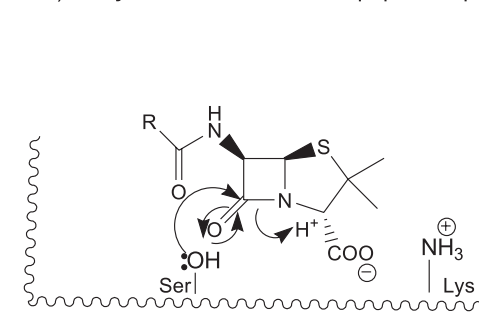

TRANSPEPTIDASE

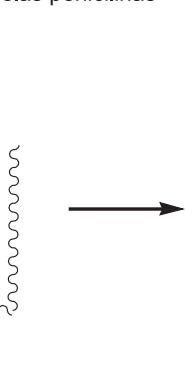

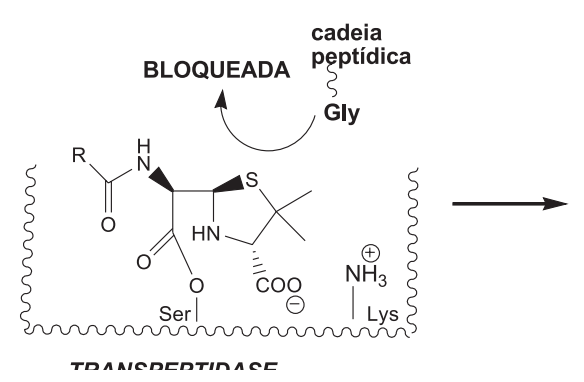

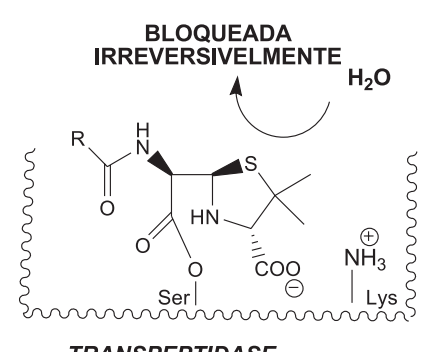

Figura 3. Mecanismo de reação da transpeptidase na formação de ligação cruzada entre cadeias peptídicas da parede celular bacteriana e inibição por antibióticos $\beta$-lactâmicos

Tabela 2. Estrutura e propriedades das principais categorias de penicilinas em uso clínico ${ }^{1}$

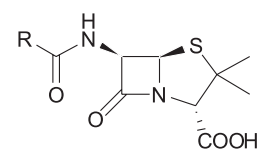

\begin{tabular}{|c|c|c|c|}
\hline Categoria & Nome & $\mathrm{R}$ & Propriedades \\
\hline $\begin{array}{l}\text { Baixo espec- } \\
\text { tro de ação, }\end{array}$ & $\begin{array}{c}\text { Penicilina G (4) } \\
\text { (benzilpenicilina) }\end{array}$ & & $\begin{array}{c}\text { Fraca estabilidade } \\
\text { ácida }\end{array}$ \\
\hline $\begin{array}{l}\text { sensível a } \\
\beta \text {-lactamases }\end{array}$ & Penicilina V (28) & & $\begin{array}{c}\text { Boa estabilidade } \\
\text { ácida }\end{array}$ \\
\hline Baixo espec- & Meticilina (29) & & $\begin{array}{c}\text { Fraca estabilidade } \\
\text { ácida }\end{array}$ \\
\hline$\beta$-lactamases & Oxacilina (30) & & $\begin{array}{c}\text { Boa estabilidade } \\
\text { ácida }\end{array}$ \\
\hline $\begin{array}{l}\text { Amplo espec- } \\
\text { tro de ação, } \\
\text { sensível a } \\
\beta \text {-lactamases }\end{array}$ & $\begin{aligned} \mathrm{R}= & \mathrm{H} \text { ampicilina } \\
\mathrm{R}= & \mathrm{OH} \text { amoxici- } \\
& \text { lina }(\mathbf{3 2})\end{aligned}$ & & $\begin{array}{c}\text { Boa estabilidade } \\
\text { ácida }\end{array}$ \\
\hline $\begin{array}{l}\text { Amplo espectro } \\
\text { de ação, anti- } \\
\text { Pseudomonas }\end{array}$ & Carbenicilina (33) & & $\begin{array}{c}\text { Fraca estabilidade } \\
\text { ácida }\end{array}$ \\
\hline $\begin{array}{l}\text { sensível a } \\
\beta \text {-lactamases }\end{array}$ & Ticarcilina (34) & & $\begin{array}{c}\text { Fraca estabilidade } \\
\text { ácida }\end{array}$ \\
\hline $\begin{array}{l}\text { Espectro de } \\
\text { ação estendido }\end{array}$ & Piperacilina (35) & & $\begin{array}{l}\text { Uso injetável, } \\
\text { ativo frente a } P \text {. } \\
\text { aeruginosa, ativi- } \\
\text { dade aumentada } \\
\text { frente a Entero- } \\
\text { bacteriaceae }\end{array}$ \\
\hline
\end{tabular}

celular através de canais proteicos de porina, embebidos na estrutura lipídica, que apresentam o interior com características hidrofílicas. Assim, antibióticos com maior atividade frente a bactérias Gram negativo são aqueles que apresentam grupos ionizáveis em suas estruturas químicas. A Tabela 2 apresenta as principais modificações estruturais encontradas em penicilinas.

O maior número de antibióticos $\beta$-lactâmicos em uso clínico pertence à classe das cefalosporinas, que estão subdivididas em cefalosporinas de primeira, segunda, terceira e quarta gerações, em função do espectro de ação mais ampliado frente a bactérias Gram negativo. O sistema bicíclico das cefalosporinas é menos tensionado em comparação ao das penicilinas, o que contribui para a maior estabilidade frente à reação de abertura intramolecular do anel $\beta$-lactâmico pela cadeia lateral. ${ }^{2,10}$ De fato, não são observados produtos de degradação cefalosporinas provenientes deste tipo de reação. A presença de grupos abandonadores ligados na posição 3 favorece a reação com a enzima transpeptidase (Figura 4B) contribuindo, portanto, para a ação antibiótica. Por outro lado, a presença de ésteres em C-3 favorece a hidrólise por esterases plasmáticas. A hidrólise por esterases leva à formação do álcool, que é um fraco grupo abandonador e, portanto, o produto reagirá mais lentamente com a enzima transpeptidase. A introdução de grupos abandonadores diferentes do éster, como piridi-

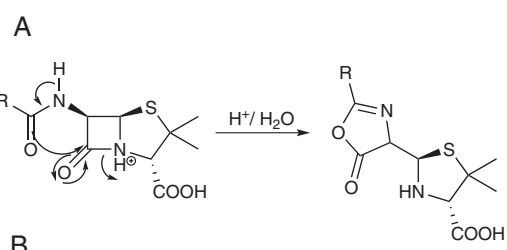

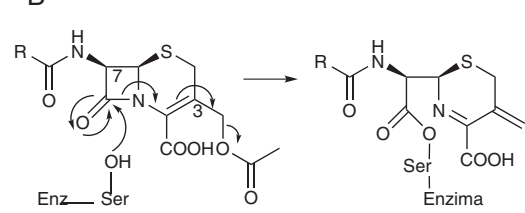

Figura 4. A- Instabilidade de penicilinas em meio ácido. B- Mecanismo de ação das cefalosporinas 


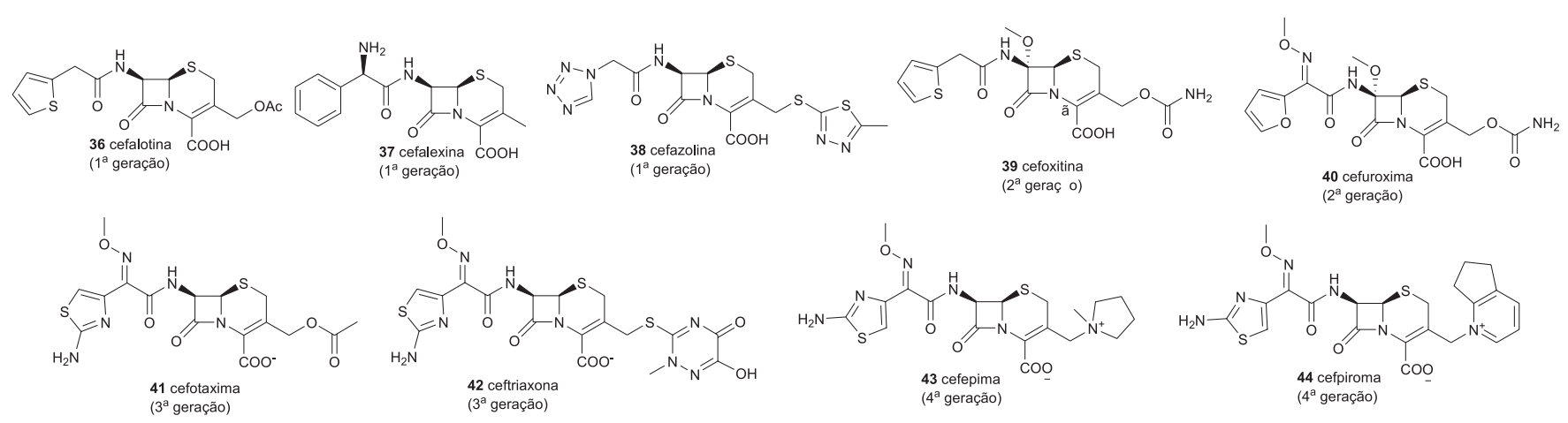

Figura 5. Exemplos selecionados de cefalosporinas de $1^{a} a ̀$ a $4^{a}$ geração

nium e carbamato, impede a hidrólise por esterases e favorece a reação com a enzima transpeptidase. Porém, estes grupos abandonadores também podem aumentar a hidrólise em meio ácido, dificultando a administração por via oral destes antibióticos. A presença de metila em C-3 favorece a absorção no trato gastrointestinal, mas diminui a velocidade de reação com a enzima transpeptidase.

Modificações em C-7 contribuem para o aumento de resistência frente às $\beta$-lactamases. Tanto a introdução de um grupamento metoxílico com configuração $\alpha$ em C-7 quanto a presença de função oximino na posição $\alpha$ ao carbono carbonílico da cadeia lateral conferem resistência às enzimas $\beta$-lactamases. A presença de anel aminotiazólico na cadeia lateral em C-7 de cefalosporinas de terceira geração aumenta a penetração do antibiótico através da membrana externa das bactérias Gram negativo. Estruturas zwitteriônicas apresentam maior atividade em bactérias Gram negativo, devido ao maior caráter hidrofílico (Figura 5).

As cefalosporinas de primeira geração são consideradas fármacos de menor atividade que as penicilinas, porém apresentam boa atividade frente a bactérias Gram positivo. Também podem ser utilizadas para tratamento de infecções por S. aureus e por Streptococcus quando as penicilinas têm que ser evitadas. As cefalosporinas de segunda geração são fármacos que, em geral, apresentam atividade variada frente a bactérias Gram positivo, porém atividade superior frente a bactérias Gram negativo. A terceira e a quarta geração das cefalosporinas também são representadas por fármacos da classe das oximinocefalosporinas. Essa classe de fármacos representa um considerável incremento na potência e no espectro de ação, particularmente frente a bactérias Gram negativo. ${ }^{2,10}$

Durante o período de maior procura por novos antibióticos, compreendido entre as décadas de 1970 e 1980, muitos subgrupos de $\beta$-lactâmicos foram relatados, tais como as monobactamas, ${ }^{9}$ representadas pelas nocardicinas (naturais) e pelo aztreonam (sintético), e as clavamas ou oxapeninas, representadas pelo ácido clavulânico (6), fármaco inativador de $\beta$-lactamases. ${ }^{1}$ Os inibidores de $\beta$-lactamases apresentam fraca ação antibiótica, devido à ausência de cadeia lateral em C-6. Porém, reagem rapida e irreversivelmente com enzimas de resistência bacteriana, com mecanismo análogo ao da reação de penicilinas e cefalosporinas com a enzima transpeptidase. São geralmente usados em combinações com penicilinas de amplo espectro de ação.

As monobactamas são antibióticos $\beta$-lactâmicos monocíclicos e foram isoladas de fontes naturais. As nocardicinas (7) apresentam atividade moderada in vivo frente a um pequeno grupo de bactérias Gram negativo, incluindo Pseudomonas aeruginosa ${ }^{2,10} \mathrm{O}$ aztreonam é um fármaco sintético da classe das monobactamas com antividade antibiótica e administrado via intravenosa. Apresenta atividade frente a micro-organismos Gram positivo e bactérias anaeróbias.,10

A tienamicina (8) foi o primeiro exemplo da classe das carbapeninas naturais e serviu de protótipo para o desenvolvimento de análogos sintéticos como imipenem, meropenem e ertapenem. As carbapeninas atuam de maneira análoga às penicilinas e cefalosporinas, com elevada potência e extraordinário espectro de atividade frente a bactérias Gram positivo e Gram negativo, além de boa resistência a $\beta$-lactamases. ${ }^{2}$

\section{Aminoglicosídeos}

Os aminoglicosídeos são agentes que possuem um grupo amino básico e uma unidade de açúcar. A estreptomicina (9), principal representante da classe, foi isolada em 1944 de Streptomyces griseus, um micro-organismo de solo. Os aminoglicosídeos apresentam atividade melhorada em $\mathrm{pH}$ levemente alcalino, em torno de 7,4, onde estão positivamente carregados, facilitando a penetração em bactérias Gram negativo. ${ }^{2}$

Os antibióticos aminoglicosídicos apresentam efeito bactericida por ligarem-se especificamente à subunidade $30 \mathrm{~S}$ dos ribossomos bacterianos, impedindo o movimento do ribossomo ao longo do mRNA e, consequentemente, interrompendo a síntese de proteínas. ${ }^{2,11}$ O uso contínuo de antibióticos aminoglicosídeos deve ser cuidadosamente controlado, devido aos efeitos ototóxicos e nefrotóxicos. Esses agentes são efetivos contra bactérias Gram negativo aeróbicas, como P. aeruginosa, e apresentam efeito sinérgico com $\beta$-lactâmicos. ${ }^{1}$

Devido à polaridade, os aminoglicosídeos devem ser administrados por via injetável. Eles também são incapazes de atravessar a barreira hemato-encefálica eficientemente e, portanto, não podem ser usados para o tratamento de meningites, a menos que sejam injetados diretamente no sistema nervoso central. ${ }^{2,11}$

\section{Macrolídeos}

Os macrolídeos representaram cerca de $18 \%$ do total de vendas de antibióticos em 2004. ${ }^{9}$ Os macrolídeos naturais caracterizam-se pela presença de lactonas macrocíclicas de origem policetídica de 14 ou 16 membros, ligadas a um açúcar e um amino-açúcar. ${ }^{1}$ Derivados semi-sintéticos podem apresentar anel macrocíclico de 15 membros (azitromicina). A eritromicina (10), isolada pela primeira vez em 1952 de Streptomyces erythreus, é um dos mais seguros antibióticos em uso clínico. ${ }^{2}$ Os macrolídeos são agentes bacteriostáticos, que atuam pela ligação com o RNA ribossomal 23S da subunidade $50 \mathrm{~S}$, interferindo na elongação da cadeia peptídica durante a translação e bloqueando a biossíntese de proteínas bacterianas. ${ }^{9,12}$ São usados em infecções respiratórias como pneumonia, exacerbação bacteriana aguda de bronquite crônica, sinusite aguda, otites médias, tonsilites e faringites. Streptococcus pneumoniae, Streptococcus pyogenes, Haemophilus influenzae e Moraxella catarrhalis são os patógenos predominantes envolvidos nestas doenças. ${ }^{9}$

A eritromicina age frente à maioria dos patógenos respiratórios, é considerada segura e amplamente prescrita a crianças. Entretanto, seu limitado espectro de ação e sua limitada estabilidade em meio 
ácido resultam em uma fraca biodisponibilidade e uma variedade de outros efeitos colaterais, tais como influência na motilidade gastrointestinal, ações pró-arrítmicas e inibição do metabolismo de fármacos. Porém, durante décadas, esforços têm sido realizados para se obter novos derivados da eritromicina, tanto de origem natural quanto sintética, com perfis mais favoráveis. Antibióticos macrolídeos de segunda geração, como roxitromicina, claritromicina e azitromicina, foram gradualmente substituindo a eritromicina, superando seu espectro de atividade, melhorando a atividade e os perfis físico-químico e farmacocinético, além de atenuar os efeitos colaterais. ${ }^{9}$

\section{Cloranfenicol}

O cloranfenicol (11) foi isolado a primeira vez do microorganismo Streptomyces venezuela. Atualmente o cloranfenicol é sintetizado e somente o isômero $R, R$ é ativo. ${ }^{2,9} \mathrm{O}$ cloranfenicol liga-se à subunidade $30 \mathrm{~S}$ do ribossomo e parece inibir o movimento dos ribossomos ao longo do mRNA, provavelmente pela inibição da peptidil transferase, responsável pela extensão da cadeia peptídica. Uma vez que o cloranfenicol se liga à mesma região que os macrolídeos e as lincosamidas, eles não podem ser administrados em associação. Os grupamentos nitro e ambos grupamentos álcool estão envolvidos nas interações. O grupo dicloroacetamida também é importante, porém pode ser substituído por outros grupos eletronegativos. ${ }^{2,9}$

\section{Tetraciclinas}

As tetraciclinas são antibióticos policetídicos bacteriostáticos de amplo espectro e bastante eficazes frente a diversas bactérias aeróbicas e anaeróbicas Gram positivo e Gram negativo. ${ }^{2,13}$ A clortetraciclina (12) foi o primeiro derivado a ser descoberto. As tetraciclinas inibem a síntese de proteínas através da ligação com a subunidade $30 \mathrm{~S}$ dos ribossomos, impedindo a ligação do aminoaciltRNA. Como resultado, a adição de novos aminoácidos para o aumento da cadeia proteica é bloqueada. A liberação de proteínas também é inibida. ${ }^{2,9}$ A seletividade frente aos ribossomos bacterianos em relação aos ribossomos de eucariotos deve-se a diferenças estruturais nos ribossomos e também à concentração seletiva do antibiótico nas células bacterianas. ${ }^{1}$ Devido ao aumento de resistência bacteriana às tetraciclinas, o seu uso como primeira escolha na terapia antibiótica tem diminuído. Entretanto, o desenvolvimento recente de um derivado semi-sintético desta classe, a tigeciclina (77), que inibe a bomba de efluxo, indica o interesse contínuo nesta classe de antibióticos. ${ }^{1}$ Devido à presença de formas de equilíbrio ceto-enólico, as tetraciclinas apresentam a capacidade de quelar metais, especialmente cálcio. Portanto, seu uso não é recomendado em crianças e mulheres grávidas, uma vez que estes antibióticos podem se acumular em dentes e ossos em formação. ${ }^{2}$

\section{Lincosamidas}

As lincosamidas têm propriedades antibacterianas similares aos macrolídeos e agem pelo mesmo mecanismo de ação. A lincomicina (13) e seu derivado semi-sintético clindamicina (14) foram introduzidos na prática clínica como antibióticos de uso oral em 1960 e 1969, respectivamente. A lincomicina foi isolada do micro-organismo de solo Streptomyces lincolnensis. A clindamicina é um antibiótico amplamente utilizado, que possui melhor atividade e maior absorção por via oral. A clindamicina é o fármaco de escolha para o tratamento de infecções periféricas causadas por Bacillus fragilis ou outras bactérias anaeróbicas penicilina resistentes. Este fármaco é também topicamente utilizado para o tratamento de acne..$^{2,9,14}$

\section{Glicopeptídeos}

Os antibióticos glicopeptídicos, vancomicina (15) e teicoplanina têm se tornado os fármacos de primeira linha no tratamento de infecções por bactérias Gram positivo com resistência a diversos antibióticos. ${ }^{15}$ A vancomicina (15), o primeiro antibiótico glicopeptídico introduzido na prática clínica em 1959, foi isolada de amostras de solo de Streptomyces orientalis (reclassificado como Amycolatopsis orientalis). A elucidação da estrutura desse antibiótico demorou vários anos, até ser completa e inequivocadamente proposta na década de $1980 .{ }^{9}$ A vancomicina apresenta uma conformação rígida importante para a atividade. Os glicopeptídeos inibem a biossíntese da parede celular bacteriana pela complexação com o resíduo dipeptídico terminal D-Ala-D-Ala das cadeias peptídicas que constituem a parede celular. Esta complexação impede que o substrato esteja disponível para a ação da transpeptidase inibindo, portanto, a reação de transpeptidação. ${ }^{1,15}$ O desenvolvimento de resistência bacteriana a estes antibióticos é mais lento, apesar de algumas linhagens de Staphylococcus aureus hospitalares já apresentarem resistência desde $1966 .{ }^{2}$ Eles são restritos para o tratamento de infecções causadas por bactérias Gram positivo por serem incapazes de penetrar nas membranas de bactérias Gram negativo. ${ }^{9,15}$ A vancomicina (15) em geral é o antibiótico de última escolha frente a patógenos Gram positivo resistentes, em particular contra espécies de Enterococcus.

\section{Lipodepsipeptídeos}

A daptomicina (20) é um lipodepsipeptídeo isolado de Streptomyces roseosporus e aprovado em 2003 para tratamento de infecções causadas por bactérias Gram positivo. Seu mecanismo de ação envolve desorganização de múltiplas funções da membrana celular bacteriana. ${ }^{2,9,12}$ É provável que todos os antibióticos lipopeptídicos apresentem alguma penetração na membrana devido às cadeias alquílicas, o que promove sua desorganização. ${ }^{1}$

\section{Rifamicinas}

A rifampicina (17) é um fármaco semi-sintético derivado da rifamicina B (16), produto natural híbrido de policetídeos e peptídeos não ribossomais. A rifamicina B (16) foi isolada de Streptomyces mediterranei, reclassificado como Nocardia mediterranei. ${ }^{1}$ A rifampicina é um inibidor da RNA polimerase, utilizada clinicamente como parte da combinação de fármacos para o tratamento da tuberculose. É o único fármaco em uso clínico que bloqueia a transcrição bacteriana. ${ }^{1,12}$

\section{Estreptograminas}

A pritinamicina é uma mistura de substâncias macrolactonas obtidas de Streptomyces pristinaespiralis, que podem ser utilizadas oralmente no tratamento de infecções por bactérias Gram positivo. Dois derivados semi-sintéticos desta classe, quinupristina e dalfopristina, têm sido utilizados por via intravenosa em combinação. ${ }^{2} \mathrm{~A}$ quinupristina (18) é derivada da pristinamicina I, uma peptideolactona cíclica não ribossonal, enquanto a dalfopristina (19) deriva da pristinamicina IIA, um híbrido policetídico/peptídico contendo um anel macrolactônico. ${ }^{1,16}$ Esses agentes atuam de maneira sinergística para bloquear a translação do polipeptídeo, pela ligação na subunidade 50S dos ribossomos bacterianos, na região 23S do rRNA, sobrepondo parcialmente o sítio de ligação dos macrolídeos. ${ }^{1,14}$ Aparentemente, a ligação da dalfopristina (19) aumenta a afinidade da ligação para a quinupristina (18), explicando o efeito sinérgico. A quinupristina (18) inibe a elongação da cadeia peptídica, enquanto a dalfopristina (19) interfere na transferência da cadeia peptídica de um tRNA para outro. ${ }^{2}$ 


\section{Antibióticos sintéticos}

\section{Sulfonamidas e trimetoprim}

As sulfonamidas, também conhecidas como sulfas, foram testadas pela primeira vez nos anos 1930 como fármacos antibacterianos. Um exemplo de sulfa ainda utilizada na terapêutica é o sulfametoxazol (22), em associação com o trimetoprim (23), para o tratamento de pacientes com infecções no trato urinário e também para pacientes portadores do vírus HIV que apresentam infecções por Pneumocystis carinii. Cada um desses fármacos bloqueia uma etapa no metabolismo do ácido fólico. ${ }^{12} \mathrm{O}$ sulfametoxazol bloqueia a enzima di-hidropteroato sintetase, presente apenas nas bactérias, enquanto o trimetoprim inibe a di-hidrofolato redutase. Ambas as enzimas atuam na via de biossíntese do $N^{5}, N^{10}$-metileno-tetra-hidrofolato, importante cofator que fornece uma unidade de carbono na biossíntese de bases pirimidínicas constituintes dos ácidos nucleicos. A atuação destes fármacos é sinérgica no bloqueio de dois diferentes passos na via bioquímica de formação deste cofator essencial. ${ }^{1}$ As sulfonamidas são, portanto, agentes bacteriostáticos que atuam como antimetabólitos do ácido $p$ aminobenzoico, substrato para a di-hidropteroato sintetase bacteriana, impedindo a formação do di-hidropteroato e, consequentemente, do $N^{5}, N^{10}$-metileno-tetra-hidrofolato. ${ }^{2}$

\section{Quinolonas e fluoroquinolonas}

As quinolonas e fluoroquinolonas são fármacos bactericidas muito utilizados no tratamento de infecções do trato urinário e também no tratamento de infecções causadas por micro-organismos resistentes aos agentes antibacterianos mais usuais. ${ }^{2}$ Esta classe representou 19\% das vendas de antibióticos em 2004. ${ }^{9} \mathrm{O}$ ácido nalidíxico (24), sintetizado em 1962, foi o protótipo desta classe de antibióticos. É ativo frente a bactérias Gram negativo e utilizado no tratamento de infecções do trato urinário, porém, os micro-organismos podem adquirir rápida resistência a esse antibiótico. Vários outros análogos têm sido sintetizados, com propriedades similares ao ácido nalidíxico. ${ }^{2} \mathrm{~A}$ enoxacina (25), desenvolvida em 1980, é um fármaco que apresenta elevado espectro de atividade frente a bactérias Gram positivo e Gram negativo. É também ativo frente à Pseudomonas aeruginosa, bactéria altamente resistente a antibióticos. $\mathrm{O}$ desenvolvimento da enoxacina (25) foi baseado na descoberta de que um átomo de flúor na posição 6 aumenta a atividade, bem como facilita a entrada na célula bacteriana. Um anel piperazínico básico na posição 7 levou ao aumento na absorção por via oral, distribuição tecidual e estabilidade metabólica. Foi observado também um aumento no nível e espectro de atividade, particularmente frente a bactérias Gram negativo como Pseudomonas aeruginosa. Muitos desses benefícios são devidos ao substituinte básico ligado à posição 7 formar um zwitterion com o ácido carboxílico da posição $3 .^{2} \mathrm{~A}$ introdução de um substituinte ciclopropílico na posição 1 incrementou o amplo espectro de ação, enquanto a substituição do nitrogênio da posição 8 por um carbono reduziu as reações adversas e aumentou a atividade frente a $S$. aureus. Estas modificações originaram a ciprofloxacina (26), o antibiótico mais ativo da classe das fluoroquinolonas frente a bactérias Gram negativo. Esse fármaco é amplamente utilizado em infecções do trato urinário, respiratório e gastrointestinal, além de infecções de pele, ossos e articulações. ${ }^{2}$

As fluoroquinolonas agem inibindo a topoisomerase IV de bactérias Gram positivo e apresentam seletividade 1000 vezes maior para enzimas bacterianas em relação às enzimas correspondentes em células humanas. Em bactérias Gram negativo, o alvo das fluoroquinolonas é a topoisomerase II, também conhecida por DNA-girase, que apresenta as mesmas funções da topoisomerase IV. ${ }^{2,17}$ As DNA-topoisomerases mudam o número de ligações no DNA superenrolado através de quebras transitórias no DNA, que se torna topologicamente relaxado devido à quebra temporária em uma fita (tipo I) ou em ambas as fitas ao mesmo tempo (tipo II). ${ }^{1,17}$ Topoisomerases são essenciais para a viabilidade celular em células procarióticas e eucarióticas. As quinolonas apresentam boa seletividade para células bacterianas.

\section{Oxazolidinonas}

A linezolida (27) é um agente bacteriostático da classe das oxazolidinonas que apresenta um amplo espectro de ação e atividade frente a bactérias resistentes a outros antibióticos que inibem a síntese de proteínas. ${ }^{18}$ A linezolida (27) liga-se à subunidade 50S ribossomal, impedindo sua união com a subunidade 30 S para formação do ribossomo 70 S, essencial para o início da síntese proteica. Desta forma, a translação não pode ser iniciada. Os outros antibióticos que inibem a síntese proteica atuam no próprio processo de translação. ${ }^{2,18}$ A linezolida (27) foi lançada em 2000 e apresenta boa atividade frente bactérias Gram positivo. Esse fármaco pode ser administrado por via oral, porém, apresenta um alto nível de efeitos colaterais. ${ }^{2,18}$

\section{RESISTÊNCIA BACTERIANA}

A resistência pode ser considerada um fenômeno ecológico que ocorre como resposta da bactéria frente ao amplo uso de antibióticos e sua presença no meio ambiente. ${ }^{19}$ As bactérias multiplicam-se rapidamente, sofrem mutação e são promíscuas, podendo trocar material genético entre linhagens de mesma espécie ou de espécies diferentes. São consideradas micro-organismos de alta capacidade de adaptação a diversos fatores, como a exposição a agentes químicos potentes. ${ }^{5,19}$

Antes do século XXI a resistência bacteriana ocorria predominantemente em ambientes hospitalares. Atualmente, a resistência bacteriana está associada a diversos ambientes e pode atingir indivíduos saudáveis. ${ }^{19}$ Uma alternativa que pode ser adotada na tentativa de contornar o problema da resistência bacteriana é o uso de terapias associadas. ${ }^{5}$ Porém, o uso extensivo e muitas vezes inapropriado dos antibióticos, más condições de higiene, fluxo contínuo de viajantes, o aumento de pacientes imunocomprometidos e a demora no diagnóstico das infecções bacterianas têm favorecido o aumento da resistência. ${ }^{9}$ Um dos mais recentes exemplos de resistência a antibióticos é a causada por patógenos intracelulares, que constituem um reservatório para infecções recorrentes. Isso ocorre quando os patógenos atacam células como os macrófagos e ficam em um estágio de dormência, protegidos dos efeitos dos antibióticos administrados. Atualmente, os antibióticos ampicilina e meropenem são capazes de combater mais eficiente e rapidamente bactérias intracelulares do que as extracelulares. ${ }^{20}$

É difícil predizer qual micro-organismo vai ser influenciado por um determinado antibiótico, pois nem sempre ocorre a resistência com o patógeno que está sendo focado no tratamento. Um exemplo foi a observação de resistência de enterococci frente à vancomicina utilizada, inicialmente, para o tratamento do patógeno Staphylococcus aureus resistente à meticilina. ${ }^{21}$

$\mathrm{O}$ conhecimento dos mecanismos bioquímicos e genéticos envolvidos na resistência bacteriana é de grande importância para se entender como a bactéria pode desenvolver a resistência. Apesar destes mecanismos variarem de patógeno para patógeno, a resistência é causada por alguns fatores básicos: inativação do antibiótico diretamente na molécula bioativa por alterações químicas, geralmente promovidas por enzimas bacterianas; ${ }^{22}$ modificação do alvo que leva à perda de sensibilidade ao antibiótico; ${ }^{23}$ mudanças na bomba de efluxo e permeabilidade externa da membrana que promovem a redução da concentração do antibiótico sem sua modificação química; ${ }^{16}$ transmissão do alvo - algumas bactérias se tornam insensíveis a alguns antibióticos porque são capazes de transmitir a inativação de uma 
determinada enzima, ou seja, os antibióticos com mecanismos de ação que envolvem inibição enzimática tornam-se inativos por não terem o alvo para atuar. ${ }^{25}$

Algumas estratégias podem ser adotadas para evitar o desenvolvimento de resistência bacteriana: prevenção de infecções bacterianas com o uso de vacinas, uso racional de antibióticos, controle e prevenção da disseminação de micro-organismos resistentes, descoberta e desenvolvimento de novos antibióticos. ${ }^{26}$ Além disso, a caracterização dos genes responsáveis pela resistência, assim como sua localização e diversidade são de grande importância para o entendimento dos fatores envolvidos na resistência. ${ }^{26}$

Atualmente, há apenas cerca de três compostos antibióticos com novos mecanismos de ação em estudos pré-clínicos Fase I, sendo que estes compostos são de amplo espectro para micro-organismos Gram positivo ou para infecções do trato respiratório. O cenário para bactérias Gram negativo é ainda mais alarmante, pois não há nenhum composto com novo mecanismo de ação em ensaios pré-clínicos. ${ }^{27}$

Aspectos econômicos são também preocupantes. As indústrias farmacêuticas desejam receber o retorno financeiro investido ao longo do processo de desenvolvimento após terem um antibiótico lançado no mercado. Entretanto, o aumento do uso de agentes antibióticos gera também o rápido aumento da resistência bacteriana, o que contribui para diminuir o tempo da patente. O investimento na busca de agentes antibióticos fica mais complicado, pois a descoberta de um antibiótico pode levar cerca de 7-10 anos e o desenvolvimento de resistência pode levar 7-8 anos. ${ }^{5}$

Os antibióticos mais recentes lançados no mercado e em estudos clínicos estão ilustrados na Figura 7 e pode-se destacar a significativa e contínua contribuição de produtos naturais microbianos nesta classe terapêutica. A tigeciclina (77), pertecente à classe das tetraciclinas, foi recentemente lançada no mercado pela indústria Wyeth. ${ }^{12}$ Os derivados glicopeptídicos dalbavancina (21), telavancina (79) e oritavancina (82) ainda estão sendo submetidos a estudos clínicos. A telavancina (79) e oritavancina (82) atuam na terminação D-alaD-ala, precursores do peptídeoglicano da parede celular bacteriana. O antibiótico $\beta$-lactâmico ceftobiprol (80) está em estudos clínicos fase III. ${ }^{12}$ Dois novos macrolídeos, telitromicina (78), lançada no mercado, e cetromicina (81), em estudos clínicos Fase III, são antibióticos que atuam no domínio $\mathrm{V}$ da região $23 \mathrm{~S}$ do rRNA. ${ }^{12} \mathrm{O}$ iclaprim (83) está em Fase III de estudos clínicos e atua na inibição da di-hidrofolato redutase. ${ }^{12}$

\section{PERSPECTIVAS PARA A DESCOBERTA E DESENVOLVIMENTO DE NOVOS ANTIBIÓTICOS}

Diversas razões justificam a necessidade urgente por novos agentes antibióticos: doenças infecciosas são a segunda maior causa de mortalidade do mundo; altas taxas de resistência microbiana, especialmente em ambientes hospitalares; o decréscimo constante observado no número total de novos agentes antimicrobianos aprovados pelo FDA $;{ }^{28}$ a necessidade de agentes que atuem por mecanismos de ação diferentes aos fármacos em uso. ${ }^{27,29}$

\section{Novas fontes de produtos naturais}

Antibióticos naturais geralmente apresentam estruturas químicas complexas importantes para as interações específicas e reconhecimento por alvos macromoleculares em bactérias patogênicas. ${ }^{30}$ Neste contexto, nos últimos 10 anos os pesquisadores têm voltado atenção para fontes naturais ainda pouco exploradas, pois organismos obtidos de novos ecossistemas estão frequentemente associados à nova diversidade química. ${ }^{31}$ Uma ampla diversidade de organismos tem sido explorada nos mais diversos habitats, especialmente em locais de condições ambientais extremas (ambientes que possuem alterações drásticas de temperatura, $\mathrm{pH}$, umidade e/ou luminosidade).

$\mathrm{O}$ crescente interesse por micro-organismos marinhos, especialmente actinobactérias, tem levado à descoberta de substâncias com atividade antitumoral e antibiótica. ${ }^{32}$ Algumas destas substâncias estão ilustradas na Figura 6. O antibiótico policíclico abissomicina C (45) foi isolado de uma actinobactéria marinha do gênero Verrucosispora e atua inibindo a síntese do ácido $p$-aminobenzoico. ${ }^{33}$ As marinomicinas A-D (46-49), macrolídeos incomuns formados por lactonas diméricas do ácido hidroxibenzoico conjugadas com cadeias policetídicas, foram isoladas da actinobactéria marinha Marinispora e apresentaram atividade antibiótica frente a Staphylococcus aureus resitente à meticilina e Enterococcus faecium resistente à vancomicina. ${ }^{34}$

Bactérias de solo ainda continuam sendo promissoras na busca de antibióticos. A platensimicina (52), isolada de Streptomyces platensi, apresentou atividade antibacteriana de amplo espectro contra Gram positivo e encontra-se em fase de estudos pré-clínicos..$^{35,36}$

Outro grupo de micro-organismos que tem sido explorado são as bactérias gliding, caracterizadas como um grupo diverso de microorganismos que possuem alta capacidade de adaptação a diferentes condições ambientais, como florestas tropicais, costa marinha, águas sujas, areias de desertos e nos tratos gastrointestinais de seres humanos e animais. Essas bactérias têm sido consideradas importantes na ecologia microbiana e compostos antibacterianos isolados destas bactérias apresentaram diferentes mecanismos de ação antibiótica, como inibição da síntese proteica, inibição de RNA polimerase e interferência na síntese da parede celular. ${ }^{37}$ Micro-organismos endofíticos, organismos não patogênicos que vivem no interior de vegetais, têm sido considerados outra fonte promissora na busca de substâncias bioativas. ${ }^{31,38}$ Recentemente, novas substâncias antimicrobianas têm sido isoladas de fungos endofíticos. ${ }^{7,39}$ Os peptídeos munumbicinas A-D, isolados de Streptomyces associado à Kennedia nigriscans, apresentaram atividade frente a diferentes bactérias resistentes à meticilina.$^{40}$ Guanacastepenos A e I (50, 51) foram isolados do fungo endofítico CR115. O guanacastepeno $A$ (50) apresentou atividade frente a cepas resistentes de Staphylococcus aureus e Enterococcus faecalis e o guanacastepeno I (51) apresentou atividade antimicrobiana frente a $S$. aureus. ${ }^{41}$

As plantas também podem contribuir na descoberta de novos antibióticos, pois é possível que produtos naturais antimicrobianos possam ser biossintetizados para prevenir e/ou combater o ataque de micro-organismos patogênicos às plantas. Gibbons ${ }^{42}$ cita vários exemplos de metabólitos isolados de plantas frente a Staphylococcus sp. Produtos naturais vegetais também têm sido apontados como inibidores de bombas de efluxo, conhecidas como "bombas de resistência a múltiplos fármacos", um novo alvo na busca de antibióticos. ${ }^{42}$

Fontes naturais pouco exploradas com interações ecológicas que podem resultar na descoberta de compostos quimicamente diversos e biologicamente ativos têm sido consideradas promissoras na busca de novos antibióticos como, por exemplo, estudos de bactérias simbiontes com insetos. ${ }^{43}$ Estudos químicos das bactérias endosimbiontes LU 2184 e LU 7314 isoladas de tecidos da pulga Ceratophyllus sp. e do intestino da larva da libélula Ceoenagrion sp., respectivamente, permitiram o isolamento de dois compostos antibacterianos: bacitracina (LU 2184) e amicoumacina B (LU 7314). ${ }^{43}$

Peptídeos antimicrobianos foram isolados do conteúdo estomacal de pingüins rei (Aptenodytes patagonicus $)^{44} \mathrm{e}$ da hemolinfa de formigas búfalo oriundas da Austrália (Myrmecia gulosa) ${ }^{45}$ Plectasina, um peptídeo com 40 resíduos de amoninoácidos foi isolado de um ascomiceto saprofítico, Pseudoplectania nigrella, e possui atividade frente a bactérias Gram positivo. ${ }^{46}$ Três tetrapeptídeos constituídos de aminoácidos incomuns foram isolados de Streptomyces sp. ${ }^{47} \mathrm{~A}$ partir do fungo Phoma sp. foram obtidas três substâncias antibióticas: ácidos fomalênicos A-C (53-55). ${ }^{48}$ 


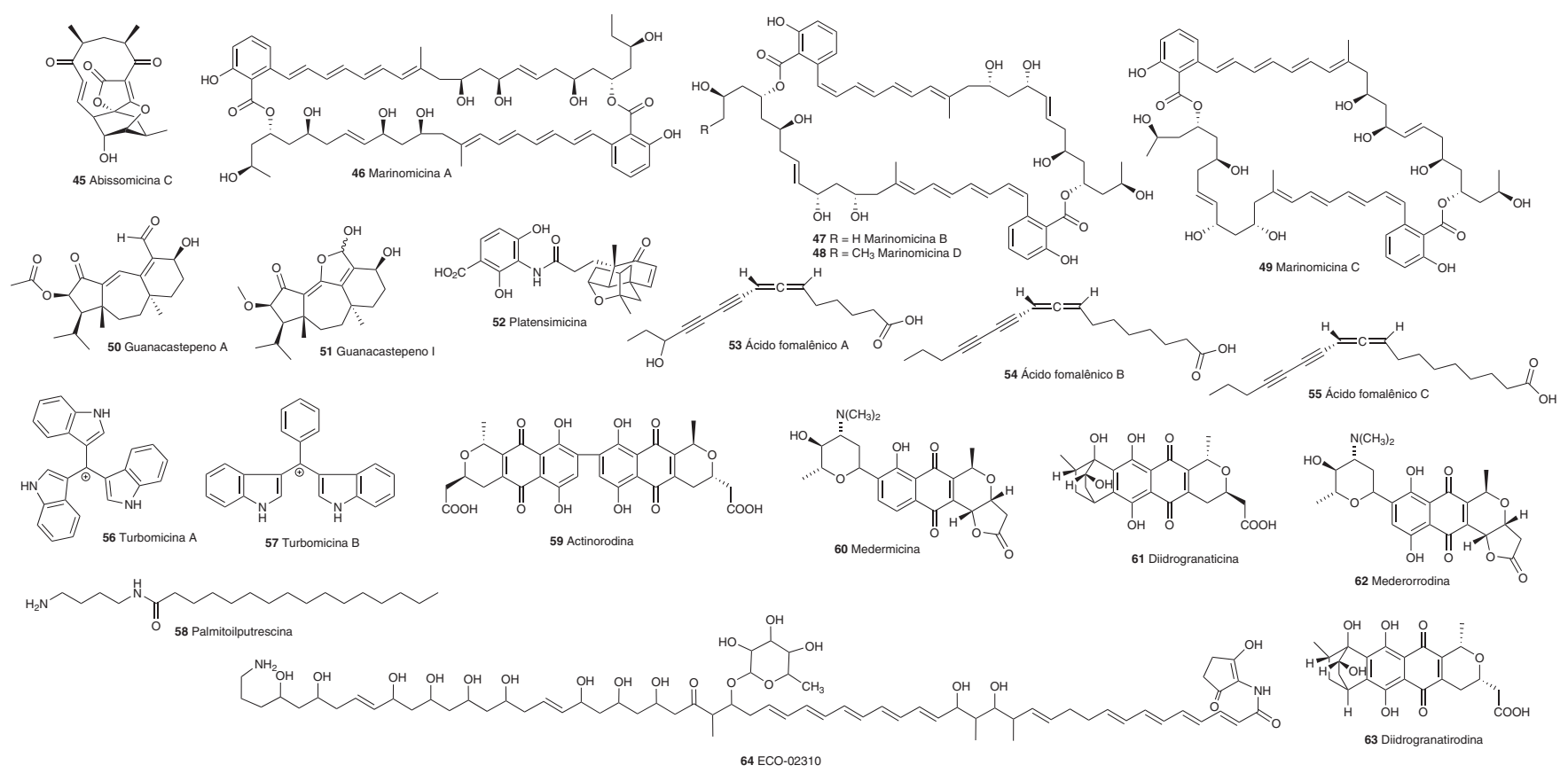

Figura 6. Substâncias com atividade antimicrobiana obtidas a partir de micro-organismos pouco explorados e através da utilização de ferramentas genômicas

\section{A contribuição da genômica na descoberta de antibióticos naturais}

Várias abordagens relacionando a química dos produtos naturais e técnicas de biologia molecular têm sido desenvolvidas visando a obtenção de moléculas naturais, que possam ser usadas como protótipos para o desenvolvimento de novos antibióticos. ${ }^{49}$

Os micro-organismos cultiváveis são reconhecidos como uma excelente fonte para a descoberta de novas moléculas bioativas, sendo responsáveis por cerca de $10 \%$ de todos os produtos naturais bioativos conhecidos. ${ }^{50}$ Porém, apenas cerca de $1 \%$ dos micro-organismos existentes são cultiváveis através de técnicas microbiológicas normalmente usadas em laboratórios. ${ }^{50}$

Atualmente, abordagens como a metagenômica, a biossíntese combinatória e a exploração genômica têm possibilitado o cultivo de um grande número de micro-organismos não cultiváveis, a diversificação de coleções de compostos através da obtenção de produtos naturais não-naturais e o acesso a clusters de genes biossintéticos silenciosos, respectivamente, gerando uma promissora expectativa quanto à descoberta de novos compostos bioativos. ${ }^{49}$

Os genomas de toda a microbiota encontrada na natureza são denominados em conjunto de metagenoma. ${ }^{51}$ Técnicas de isolamento do metagenoma do solo permitem que o DNA de toda comunidade microbiana seja diretamente extraído do ambiente, $e$ DNA (do inglês environmental DNA). Através da expressão heteróloga do e DNA em hospedeiros facilmente cultiváveis, como Escherichia coli, os respectivos produtos naturais codificados pelo metagenoma de micro-organismos não cultiváveis podem ser produzidos, isolados, identificados e avaliados biologicamente. ${ }^{51}$ Como a produção de antibióticos geralmente está relacionada a vias complexas de biossíntese inseridas em extensas regiões do DNA, a clonagem dessas vias é uma atividade bastante complexa. ${ }^{29} \mathrm{O}$ emprego desse tipo de técnica pode gerar uma boa expectativa na descoberta de novos antibióticos, porém uma das limitações desse método é que o hospedeiro pode não expressar o fragmento de DNA incorporado. ${ }^{29} \mathrm{~A}$ descoberta das turbomicinas A-B $(\mathbf{5 6}, \mathbf{5 7})^{52}$ e da palmitoilputrescina $(\mathbf{5 8})^{53}$ utilizando técnicas metagenômicas ilustra o potencial desta abordagem na busca de novos antibióticos. Mais recentemente, a abordagem metagenômica foi aplicada na busca de genes específicos relacionados a enzimas envolvidas em acoplamento oxidativo na biossíntese de antibióticos glicopeptíticos, resultando no isolamento de dois novos clusters de genes. ${ }^{54}$ Após estudos de reconstituição in vitro e expressão heteróloga destes clusters de genes, sete novos análogos aglicônicos sulfatados da teicoplanina foram isolados e identificados, com atividade antibiótica semelhante à vancomicina e teicoplanina frente a Staphylococcus aureus. ${ }^{54}$

A biossíntese combinatória envolve a engenharia genética das vias biossintéticas naturais para a produção de novos compostos usando a maquinaria biossintética existente em cada organismo, especialmente para obtenção de antibióticos derivados policetídeos e peptídeos não ribossomais. ${ }^{55}$ Esta possibilidade foi primeiramente demonstrada por Hopwood et al..${ }^{56}$ que clonou os genes biossintéticos do antibiótico actinorodina (59) de Streptomyces coelicolor nos micro-organismos produtores de medermicina (60) e di-hidrogranaticina (61), respectivamente. O actinomiceto Streptomyces sp. AM-7161 modificado geneticamente produziu, além de medermicina (60), grandes quantidades de uma nova substância mederorrodina (62), a qual contém um grupo hidroxila adicional característico da actinorodina. Streptomyces violaceoruber Tü 22, modificado para produzir di-hidrogranaticina (61), produziu uma nova substância, di-hidrogranatirodina (63), preservando as configurações dos precursores nos estereocentros da nova molécula. Este trabalho representa a primeira utilização do conceito de biossíntese combinatorial de produtos naturais e abriu uma nova perspectiva para a diversificação estrutural de produtos naturais de interesse. ${ }^{51}$ Um exemplo mais recente de sucesso para a biossíntese combinatorial foi a manipulação genética das vias biossintéticas de Streptomyces roseosporus, produtor da daptomicina (20), que originou uma plataforma robusta com mais de 60 novos antibióticos lipopetídicos, os quais seriam dificilmente obtidos por síntese química. ${ }^{57} \mathrm{~A}$ engenharia metabólica, caracterizada pela combinação de deleções de genes e expressões de genes externos através de vetores de expressão replicativos, também tem sido usada com sucesso para gerar variações estruturais de antibióticos aminocumarínicos. ${ }^{58}$

Outro aspecto da genômica que tem sido adotado para a busca de substâncias antibióticas é a identificação de clusters de genes associados com a biossíntese de antibióticos, denominada de "ex- 


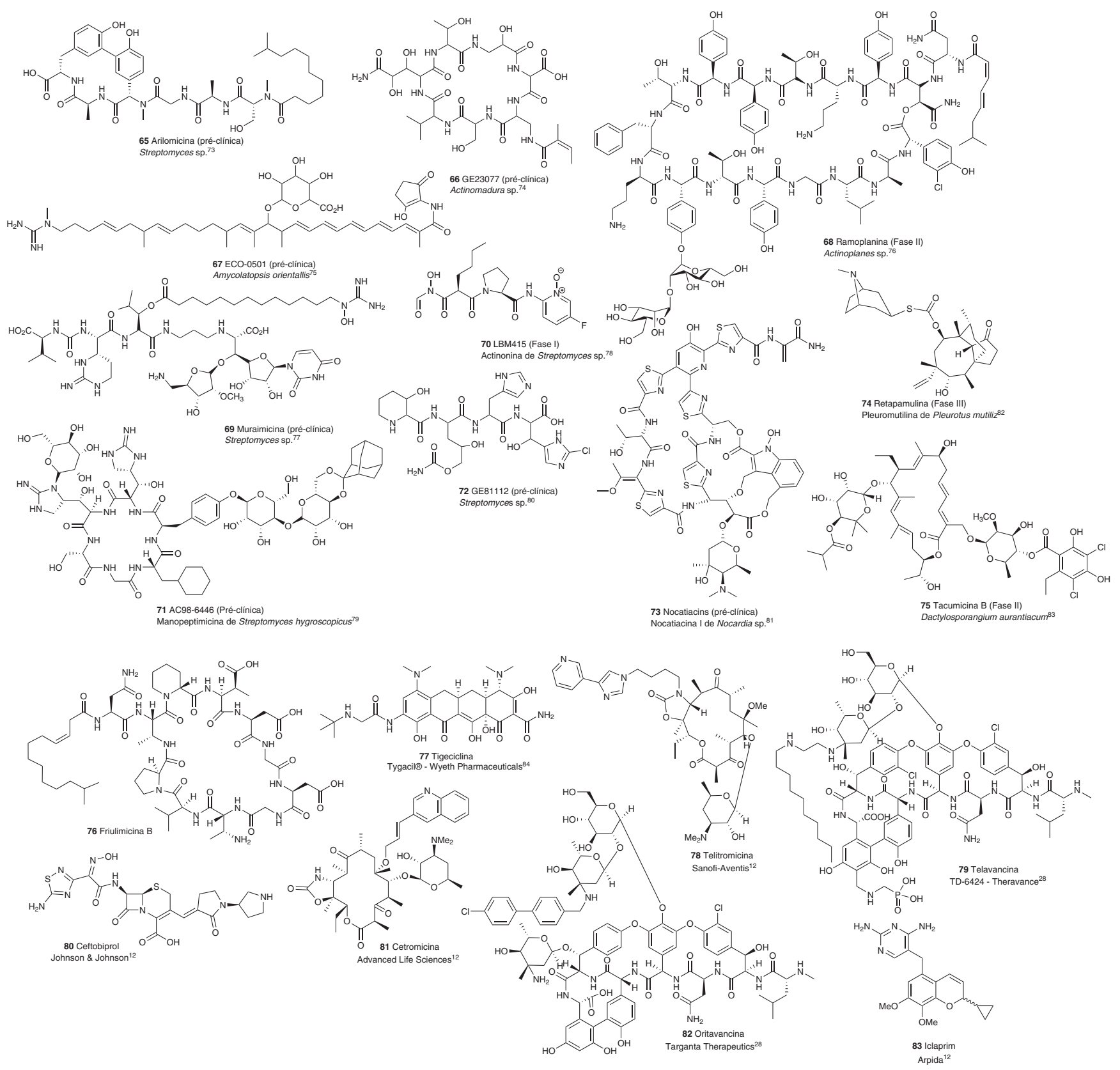

Figura 7. Antibióticos recentes introduzidos no mercado farmacêutico e em estudos clínicos

ploração genômica" (genome mining), que possibilita a identificação de genes que não são expressos em condições usuais de cultivo. ${ }^{59,60}$ Esta abordagem associa a informação genética primária à função das respectivas enzimas biossintéticas, possibilitando a identificação de novos produtos naturais. $\mathrm{O}$ isolamento e identificação do composto coeloquelina a partir de Streptomyces coelicolor demonstra uma efetiva contribuição desta técnica para a descoberta de agentes antimicrobianos. ${ }^{61} \mathrm{O}$ potente agente antifúngico ECO-02301 (64) também foi identificado através da exploração genômica em Streptomyces aizunensis. ${ }^{59}$

\section{Novos mecanismos de ação antibiótica}

Entre os 10 antibióticos aprovados desde 1998, somente a oxazolidinona linezolida (27) e o lipodepsipeptídeo daptomicina (20) apresentaram novos mecanismos de ação. ${ }^{62}$ Há poucos relatos de compostos antimicrobianos que desempenham diferentes mecanismos de ação como nova estratégia para o combate a doenças infecciosas. O composto friulimicina B (76) é um dos poucos exemplos. Esta substância encontra-se em Fase I de estudos pré-clínicos, iniciada na Suíça em junho de 2007. Apesar da friulimicina B apresentar similaridade química com a daptomicina, ela é o primeiro membro da nova classe de antibióticos lipopeptídicos bactericidas que parece interferir na inibição da formação do lipídeo I, um precursor na síntese de peptideoglicanos da parede celular. ${ }^{28}$

Apesar dos nucleosídeos simples possuírem mecanismos de ação já descritos, agindo especialmente como inibidores da síntese de ácidos nucleicos, os derivados acil- e glicosil-nucleosídicos possuem mecanismos de ação mais diferenciados e complexos. Por exemplo, a puromicina e nucleocidina podem agir como inibidores da síntese de ácidos nucleicos ou proteínas ou síntese de glicanos, enquanto as nicomicinas inibem a síntese de quitina da parede celular fúngica. ${ }^{63}$

Fármacos com novos mecanismos de ação deverão apresentar vantagens no combate a micro-organismos resistentes e à emergência 
de novos patógenos. Butler e Buss ${ }^{64}$ ilustram alguns compostos com potencial para novas classes de antibióticos, destacando-se arilomicina, manopeptimicina, muraimicina, caprazamicina e nocatiacina, além de outros compostos em fase de estudos clínicos. ${ }^{64}$

Novas estratégias têm sido desenvolvidas na tentativa de otimizar processos de elucidação de mecanismos de ação de candidatos a fármacos antibióticos, como ensaios baseados em microarray e biomarcadores . Essa técnica consiste em três etapas fundamentais: construção de uma base de dados com as respostas transcricionais de uma bactéria frente a diferentes compostos antibióticos; padronização das concentrações e tempo de exposição dos antibióticos no ensaio com mecanismos de ação ainda desconhecidos e a determinação de genes transcritos envolvidos em novos mecanismos de ação. A análise dos dados é realizada comparando-se respostas de diferentes antibióticos com mecanismos de ação conhecidos com compostos de mecanismos de ação desconhecidos. Os resultados são obtidos através das respostas antibióticas baseadas em dados microarray dos mecanismos de ação de antibióticos conhecidos em função das respostas transcricionais de uma bactéria (deve ter sequenciamento genético previamente caracterizado) por biomarcadores frente ao composto do qual se deseja determinar o mecanismo de ação. ${ }^{65}$

\section{Novos ensaios antibacterianos}

Os ensaios celulares caracterizam-se pela detecção dos efeitos que um composto apresenta frente ao crescimento celular. Esta triagem baseada na análise do fenótipo pode ser informativa acerca de interações entre os compostos e o sistema celular submetido no ensaio, porém não é possível obter nenhuma informação acerca do mecanismo de ação pelo qual as substâncias atuam, já que a resposta fenotípica observada pode estar relacionada a uma grande variedade de alvos responsáveis pelos efeitos biológicos observados ${ }^{66}$ Além disso, uma desvantagem desta abordagem é que a presença de compostos citotóxicos em extratos brutos pode mascarar o potencial de outros compostos. ${ }^{67}$

Atualmente, ensaios high-throughput screening (HTS) têm sido amplamente empregados para a descoberta e desenvolvimento de novos fármacos. Esses ensaios são realizados por equipamentos automatizados, comumente conhecidos como robotizados, que permitem triagens in vitro e in vivo de grandes coleções de compostos. Os ensaios HTS permitem uma rápida análise na identificação de compostos bioativos com aplicações químicas e biológicas. ${ }^{68}$

Alguns alvos possuem alta probabilidade de sucesso na busca de compostos antibacterianos: transglicosilase, que tem importante função na formação de substratos lipoglicopeptídicos para formação da parede celular tem sido alvo para ensaios HTS; a síntese proteica bacteriana tem sido explorada a nível ribossomal utilizando técnicas de cristalografia de raios- $X$ a fim de se verificar em qual região do RNA ribossomal o antibiótico se liga; em bactérias Gram positivo a busca de inibidores de enzimas sortases, relacionadas à formação da parede de peptideoglicano, podem ser alvos para agentes bactericidas e/ou bacteriostáticos; enzimas que participam da via de biossíntese do isopreno, descritas no metabolismo de várias bactérias patogênicas, têm sido consideradas alvos interessantes, pois são enzimas diferentes das encontradas em seres humanos. ${ }^{30}$

Alvos envolvendo múltiplas enzimas são priorizados devido a uma maior probabilidade de se encontrar moléculas capazes de se ligarem a uma ou mais unidades, além de serem alvos mais difíceis de favorecerem a resistência. ${ }^{27}$ Alvos envolvendo a virulência, que pode ser promovida por intermédio de moléculas sinalizadoras em processos quorum sensing, também têm sido explorados a fim de se detectar fatores responsáveis pela patogenicidade. Nas bactérias, as células monitoram sua densidade populacional por meio de sinais químicos, os quais têm sua produção favorecida em função do crescimento celular bacteriano. Após um limiar de concentração de densidade populacional as moléculas quorum sensing podem induzir diferentes comportamentos para a comunidade bacteriana como bioluminescência, produção de antibióticos, formação de biofilme, virulência, esporulação e capacidade de adaptação. ${ }^{67,69}$

Recentemente, informações sobre estrutura molecular de alta resolução de ribossomos têm contribuído para o desenvolvimento de novos antibióticos que atuam a nível ribossomal, pois permitem observar quais características conectivas a nível atômico dos ribossomos e seus ligantes são importantes. ${ }^{70}$

Em muitas bactérias, a expressão de um determinado número de genes crucial para o metabolismo é regulada por estruturas do mRNA conhecidas como riboswitches. Em algumas bactérias patogênicas, essas regiões regulam a expressão genética essencial para a sobrevivência ou virulência do micro-organismo. Portanto, pode-se predizer que metabólitos que interajam nas regiões riboswitches podem causar efeitos letais para as bactérias, já que o composto mimético não pode desempenhar funções semelhantes ao ligante natural. Pesquisas têm sido conduzidas utilizando essas regiões como alvos para compostos antibacterianos. $^{71}$

Porém, tanto os ensaios bioquímicos quanto os ensaios celulares apresentam desvantagens por desconsiderarem a presença do hospedeiro infectado. É importante considerar que i) algumas doenças afetam um organismo como um todo, e a maioria dos organismos não pode ser reconstituída in vitro; ii) células e organismos estão fisiologicamente correlacionados e esta interface pode ser crítica para o desenvolvimento de algumas doenças, o que não pode ser reconstituído in vitro; iii) o progresso de uma doença também não pode ser construído in vitro. Com isso, vários hits promissores apresentam falhas quando submetidos a ensaios de toxicidade e eficácia in vivo. Isso ocorre porque tanto os patógenos quanto as substâncias submetidas a esses tipos de ensaios se comportam diferentemente quando observadas in vitro e no hospedeiro. Uma alternativa é a utilização de mamíferos, como ratos e cobaias, infectados com micro-organismos patogênicos. Porém, esses ensaios têm um alto custo e aspectos éticos envolvidos. ${ }^{72}$ Organismos invertebrados com genética bem caracterizada, como Drosophylla, Caenorhabditis elegans e Arabidopsis thaliana têm sido utilizados como hospedeiros de micro-organismos patogênicos caracterizando novos modelos biológicos na busca de agentes antimicrobianos. ${ }^{72}$

Caenorhabditis elegans e Danio rerio (zebrafish) têm sido utilizados em ensaios antibacterianos, contribuindo para um ensaio in vivo mais informativo, onde podem ser descobertos compostos com atividade in vivo, incluindo pró-fármacos; compostos que atuam sobre a virulência do micro-organismo utilizado no ensaio ou compostos que aumentam a resposta imune do hospedeiro. Além disso, podem ser detectados possíveis efeitos tóxicos dos compostos, o ensaio pode ser realizado em HTS e a infecção pode ser monitorada em tempo real. ${ }^{72}$

Vale mencionar que muitos protótipos não são adequados ao futuro desenvolvimento de fármacos devido a problemas relacionados à farmacocinética. Com estas características, ensaios baseados em modelos de infecção in vivo podem levar à identificação de novas substâncias ativas com maior quantidade de informações agregadas, o que pode agilizar o processo de desenvolvimento de eventuais antibióticos a partir dos protótipos descobertos. ${ }^{72}$

\section{CONCLUSÕES}

As novas estratégias da pesquisa em produtos naturais microbianos, envolvendo a busca de substâncias em micro-organismos pouco explorados e a utilização de ferramentas genômicas para o acesso a novos produtos naturais, aliadas aos novos ensaios biológi- 
cos adotados nas triagens, podem acelerar o processo de descoberta de novos antibióticos, extremamente importantes num cenário de rápido desenvolvimento de resistência pelas bactérias aos agentes terapêuticos disponíveis.

A ampla biodiversidade existente no mundo combinada às diversas técnicas citadas neste trabalho indica que novos compostos antibióticos podem ser descobertos através da pesquisa com microorganismos ou outras fontes naturais.

\section{AGRADECIMENTOS}

Ao apoio financeiro da FAPESP (Fundação de Amparo à Pesquisa do Estado de São Paulo), CAPES (Coordenação de Aperfeiçoamento de Pessoal de Nível Superior) e CNPq (Conselho Nacional de Desenvolvimento Científico e Tecnológico) pelo apoio financeiro às pesquisas na forma de auxílios e bolsas de pesquisa.

\section{REFERENCIAS}

1. Walsh, C.; Antibiotics: Actions, Origins, Resistence, ASM Press: Washington, 2003.

2. Patrick, G. L.; An Introduction to Medicinal Chemistry, Oxford University Press: New York, 2005, cap.16; Patrick, G. L.; An Introduction to Medicinal Chemistry, Oxford University Press: New York, 1995, cap. 10.

3. Nicolaou, K. C.; Montagnon, T.; Molecules that Changed the World, Wiley-VCH: Weinheim, 2008, cap. 13.

4. Projan, S. J.; Shlaes, D. M.; Clin. Microbiol. Infec. 2004, 10, 18.

5. Fernandes, P.; Nat. Biotechnol. 2006, 24, 1497.

6. http://www.fda.gov, acessada em Fevereiro 2009

7. Pupo, M. T.; Guimarães, D. O.; Furtado, N. A. J. C.; Borges, W. S. Em Modern Biotechnology in Medicinal Chemistry and Industry; Taft, C. A., ed.; Research Signpost: Kerala, 2006, cap. 4.

8. Abraham, D. J.; Burger's Medicinal Chemistry \& Drug Discovery. Chemotherapeutic Agents, John Wiley \& Sons: San Francisco, 2003, vol. 5.

9. von Nussbaum, F.; Brands, M.; Hinzen, B.; Weigand, S.; Häbich, D.; Angew. Chem., Int. Ed. 2006, 45, 5072.

10. Suaréz, C.; Gudiol, F.; Enferm. Infecc. Microbiol. Clin. 2009, 27, 116.

11. Durante-Mangoni, E.; Grammatikos, A.; Utili, R.; Falagas, M. E.; Int. J. Antimicrob. Ag. 2009, 33, 201.

12. Brötz-Oesterhelt, H.; Brunner, N. A.; Curr. Opin. Pharmacol. 2008, 8, 564.

13. Wright, G. D.; Chu, D. T. W. Em ref. 8, vol. 5, cap. 15.

14. Mukhtar, T. A.; Wright, G. D.; Chem Rev. 2005, 105, 529.

15. Pace, J. L: Yang, G.; Biochem. Pharmacol. 2006, 71, 968.

16. Allington, D. R.; Rivey, M. P.; Clin. Ther. 2001, 23, 24.

17. Drlica, K.; Malik, M.; Kerns, R. J.; Zhao, X.; Antimicrob. Agents Ch. 2008, 52, 385.

18. Bozdogan, B.; Appelbaum, P. C.; Int. J. Antimicrob. Ag. 2004, 23, 113.

19. Levy, S. B.; Clin. Infect. Dis. 2001, 33, S124; Demain, A. L.; Nat. Biotechnol. 2002, 20, 331 ; Woodford, N.; Clin. Microbiol. Infec. 2005, 11, 2.

20. Abeylath, S. C.; Turos, E.; Expert Opin. Drug Deliv. 2008, 5, 931.

21. Hiramatsu, K.; Aritaka, N.; Hanaki, H.; Kawasaki, S.; Hosoda, Y.; Hori, S.; Fukichi, Y.; Kobayashi, I.; Lancet 1997, 350, 1670.

22. Wright, G. D.; Adv. Drug Delivery Rev. 2005, 57, 1451.

23. Lambert, P. A.; Adv. Drug Delivery Rev. 2005, 57, 1471.

24. Kumar, A.; Schweizer, H. P.; Adv. Drug Delivery Rev. 2005, 57, 1486.

25. Happi, C. T.; Gbotosho, G. O.; Folarin, O. A.; Akinbove, D. O.; Yusuf, B. O.; Ebong, O. O.; Sowunmi, A.: Kyle, D. E.; Milhous, W.; Wirth, D. T.; Oduola, A. M. J.; Acta Trop. 2005, 95, 183; Mobashery, S.; Azucena, E. F. Em Encyclopedia of Life Sciences, Nature Publishing Group: London, 2002, http://www.mrw.interscience.wiley.com/emrw/9780470015902/els/ article/a0001993/current/pdf, acessada em Novembro 2008.

26. Moellering, R. C. Jr.; Clin. Infect. Dis.1998, 27, S135; Dzidic, S.; Suskovic, J.; Kos, B.; Food Technol. Biotech. 2008, 46, 11.
27. Payne, D. J.; Gwynn, M. N.; Holmes, D. J.; Pampliano, D. L.; Nat. Rev. Drug Discovery 2007, 6, 29.

28. Luzhetskyy, A.; Pelzer, S.; Bechthold, A.; Curr. Opin. Investig. D 2007, 8,608 .

29. Coates, A. R. M.; Hu, Y.; Br. J. Pharmacol. 2007, 152, 1147.

30. Walsh, C. T.; Nat. Rev. Microbiol. 2003, 1, 65.

31. Clardy, J.; Walsh, C.; Nature 2004, 432, 829.

32. Mincer, T. J.; Jensen, P. R.; Kauffman, C. A.; Fenical, W.; Appl. Environ. Microbiol. 2002, 68, 5005; Bull, A. T.; Stach, J. E. M.; Trends Microbiol. 2007, 15, 491.

33. Bister, B.; Bischoff, D.; Ströbele, M.; Riedlinger, J.; Wolter, F.; Bull, A. T.; Zähner, H.; Fiedler, H.- P.; Süssmuth, R. D.; Angew. Chem., Int. Ed. 2004, 43, 2574 .

34. Kwon, H. C.; Kauffman, C. A.; Jensen, P. R.; Fenical, W.; J. Am. Chem. Soc. 2006, 128, 1622.

35. Wang, J.; Soisson, S. M.; Young, K.; Shoop, W.; Kodali, S.; Galgoci, A.; Painter, R.; Parthasarathy, G.; Tang, Y. S.; Cummings, R.; Ha, S.; Dorso, K.; Motyl, M.; Jayasuriya, H.; Ondeyka J.; Herath, K.; Zhang, C.; Hernandez, L.; Allocco, J.; Basilio, A.; Tormo, J. R.; Genilloud, O.; Vicente, F.; Pelaez, F.; Colwell, L.; Lee, S. H.; Michael, B.; Felcetto, T.; Gill, C.; Silver, L. L.; Hermes, J. D.; Bartizal, K.; Barrett, J.; Schmatz, D.; Becker, J. W.; Cully, D.; Singh, S. B.; Nature 2006, 441, 358.

36. Pearson, H.; Nature 2006, 441, 260.

37. Nett, M.; König, G. M.; Nat. Prod. Rep. 2007, 24, 1245.

38. Gunatilaka, A. A. L.; J. Nat. Prod. 2006, 69, 509.

39. Gallo, M. B. C.; Guimarães, D. O.; Momesso, L. S.; Pupo, M. T. Em Microbial Biotechnology; Saikai, R.; Bezbaruah, R. L.; Bora, T. C., eds.; New India Publishing Agency: New Delhi, 2008, cap. 7; Borges, W. S.; Borges, K. B.; Bonato, P. S.; Said, S.; Pupo, M. T.; Curr. Org. Chem. 2009, 13, 1137.

40. Castillo, U. F.; Strobel, G. A.; Ford, E. J.; Hess, W. M.; Porter, H.; Jensen, J. B.; Albert, H.; Robison, R.; Condron, M. A. M.; Teplow, D. B.; Stevens, D.; Yaver, D.; Microbiology 2002, 148, 2675.

41. Brady, S. F.; Bondi, S. M.; Clardy, J.; J. Am. Chem. Soc. 2001, 123, 9900 .

42. Gibbons, S.; Nat. Prod. Rep. 2004, 21, 263; Lewis, K.; Ausubel, F. M.; Nat. Biotechnol., 2006, 24, 1504.

43. Gebhardt, K.; Schimana, J.; Müller, J.; Fiedler, H.-P.; Kallenborn, H. G.; Holzenkämpfer, M.; Krastel, P.; Zeeck, A.; Vater, J.; Höltzel, A.; Schmid, D. G.; Rheinheimer, J.; Dettner, K.; FEMS Microbiol. Lett. 2002, 217, 199.

44. Thouzeau, C.; Maho, Y. L.; Froget, G.; Sabatier, L.; Bohec, C. L.; Hoffman, J. A.; Bulet, P.; J. Biol. Chem. 2003, 278, 51053.

45. Mackintosch, J. A.; Trimble, J. E.; Jones, M. K.; Karuso, P. H.; Beattie, A. J.; Veal, D. A.; Can. J. Microbiol. 1995, 41, 136.

46. Mygind, P. H.; Fischer, R. L.; Schnorr, K. M.; Hansen, M. T.; Sonksen, C. P.; Ludvigsen, S.; Raventos, D.; Buskov, S.; Christensen, B.; De, M. L.; Taboureau, O.; Yaver, D.; Elvig-Jorgensen, S. G.; Sorensen, M. V.; Christensen, B. E.; Kjaerulff, S.; Frimodt-Moller, N.; Lehrer, R. I.; Zasloff, M.; Kristensen, H. H.; Nature 2005, 437, 975.

47. Brandi, L.; Lazzrini, A.; Cavaletti, L.; Abbondi, M.; Corti, E.; Ciciliato, I.; Gastaldo, L.; Marazzi, A.; Feroggio, M.; Fabbretti, A.; Maio, A.; Colombo, L.; Donadio, S.; Marinelli, F.; Losi, D.; Gualerzi, C. O.; Selva, E.; Biochemistry 2006, 45, 3692.

48. Ondeyka, J. G.; Zink, D. L.; Young, K.; Painter, R.; Kodali, S.; Galgoci, A.; Collado, J.; Tormo, J. R.; Basilio, A.; Vicente, F.; Wang, J.; Singh, S. B.; J. Nat. Prod. 2006, 69, 377.

49. Pupo, M. T.; Gallo, M. B. C.; Vieira, P. C.; Quim. Nova 2007, 30, 1446; Lefevre, F.; Robe, P.; Jarrin, C.; Ginolhac, A.; Zago, C.; Auriol, D.; Vogel, T. M.; Simonet, P.; Nalin, R.; Res. Microbiol. 2008, 159, 153.

50. Bérdy, J.; J. Antibiot. 2005, 58, 1; Brady, S. F.; Nat. Protoc. 2007, 2, 1297. 
51. Handelsman, J.; Rondon, M. R.; Brady, S. F.; Clardy, J.; Goodman, R. M.; Chem. Biol. 1998, 5, R245; Rondon, M. R.; August, P. R.; Bettermann, A. D.; Brady, S. F.; Grossman, T. H.; Liles, M. R.; Loiacono, K. A.; Lynch, B. A.; MacNeil, I. A.; Minor, C.; Tiong, C. L.; Gilman, M.; Osburne, M. S.; Clardy, J.; Handelsman, J.; Goodman, R. M.; Appl. Environ. Microbiol. 2000, 66, 2541.

52. Gillespie, D. E.; Brady, S. F.; Bettermann, A. D.; Cianciotto, N. P.; Liles, M. R.; Rondon, M. R.; Clardy, J.; Goodman, R. M.; Handelsman, J.; Appl. Environ. Microb. 2002, 68, 4301.

53. Brady, S. F.; Clardy, J.; J. Nat. Prod. 2004, 67, 1283.

54. Banik, J. J.; Brady, S. F.; Proc. Natl. Acad. Sci. U. S. A. 2008, 105, 17273.

55. Wright, G. D.; Sutherland, A. D.; Trends Mol. Med. 2007, 13, 260.

56. Hopwood, D.A.; Malpartida, F.; Kieser, H.M.; Ikeda, H., Duncan, J.; Fujii, I.; Rudd, B. A. M.; Floss, H. G.; Omura, S.; Nature 1985, 314, 642.

57. Baltz, R. H.; Brian, P.; Miao, V.; Wrigley, S. K.; J. Ind. Microbiol. Biotechnol. 2006, 33, 66.

58. Heide, L. Em Complex Enzymes in Microbial Natural Product Biosynthesis, Part B: Polyketides, Aminocoumarins and Carbohydrates; Hopwood, D. A., ed.; Academic Press: San Diego, 2009, cap. 18.

59. McAlpine, J. B.; Bachmann, B. O.; Piraee, M.; Tremblay, S.; Alarco, A.-M.; Zazopoulos, E.; Farnet, C. M.; J. Nat. Prod. 2005, 68, 493.

60. Bergmann, S.; Schümann, J.; Schrlach, K.; Lange, C.; Brakhage, A. A.; Hertweck, C.; Nat. Chem. Biol. 2007, 3, 213.

61. Lautru, S.; Deeth, R. J.; Bailey, L. M.; Challis, G. L.; Nat. Chem. Biol. 2005, 1, 265.

62. Mills, S. D.; Biochem. Pharmacol. 2006, 71, 1096.

63. Rachakonda, S.; Cartee, L.; Curr. Med. Chem. 2004, 11, 775.

64. Butler, M. S.; Buss, A. D.; Biochem. Pharmacol. 2006, 71, 919.

65. Freiberg, C.; Brunner, N.; Macko, L.; Fischer, H. P.; Mol. Cell. Proteomics 2006, 5, 2326.

66. Gaweska, H.; Kielec, J.; McCafferty, D.; Chem. Biol. 2004, 11, 1330.

67. Baker, D. D.; Chu, M.; Oza, U.; Rajgarhia, V.; Nat. Prod. Rep. 2007, 24, 1225.

68. Fernandes, T. G.; Diogo, M. M.; Clark, D. S.; Dordick, J. S.; Cabral, J. M. S.; Trends Biotechnol. 2009, 27, 342.

69. Chen, H.; Fujita, M.; Feng, Q.; Clardy, J.; Fink, G. R.; Proc. Natl. Acad. Sci. U. S. A. 2004, 101, 5048; Whitehead, N. A.; Barnard, M. L.; Slater, H.; Simpson, N. J. L.; Salmond, G. P. C.; FEMS Microbiol. Rev. 2001 , 25,365 .
70. Yusupov, M. M.; Yusupova, G. Z.; Baucom, A.; Lieberman, K.; Earnest, T. N.; Cate, J. H. D.; Noller, H. F.; Science 2001, 292, 883; Berisio, R.; Schluenzen, F.; Harms, J.; Bashan, A.; Auerbach, T.; Baram, D.; Yonath, A.; Nat. Struct. Biol. 2003, 10, 366; Moore, P. B.; Steitz, T. A.; Annu. Rev. Biochem. 2003, 72, 813.

71. Blount, K. F.; Breaker, R. R.; Nat. Biotechnol. 2006, 24, 1558.

72. Mukhopadhyay, A.; Peterson, R. T.; Curr. Opin. Chem. Biol. 2006, 10, 327; Ségalat, L.; ACS Chem. Biol. 2007, 2, 231; Moy, T. I.; Ball, A. R.; Anklesaria, Z.; Casadei, G.; Lewis, K.; Ausubel, F. M.; Proc. Natl. Acad. Sci. U. S. A. 2006, 103, 10414; Van Der Sar, A. M.; Appelmelk, B. J.; Vanderbroucke-Grauls, C. M. J. E.; Bitter, W.; Trends Microbiol. 2004, 12,451 .

73. Kulanthaivel, P.; Kreuzman, A. J.; Strege, M. A.; Belvo, M. D.; Smitka, T. A.; Clemens, M.; Swartling, J. R.; Minton, K. L.; Zheng, F.; Angleton, E. L.; Mullen, D.; Jungheim, L. N.; Klimkowski, V. J.; Nicas, T. I.; Thompson, R. C.; Peng, S. B.; J. Biol. Chem. 2004, 279, 36250.

74. Mariani, R.; Granata, G.; Maffioli, S. I.; Serina, S.; Brunati, C.; Sosio, M.; Marazzi, A.; Vannini, A.; Patel, D.; White, R.; Ciabatti, R.; Bioorg. Med. Chem. Lett. 2005, 15, 3748.

75. Banskota, A. H.; McAlpine, J. B.; Sorensen, D.; Ibrahim, A.; Aouidate, M.; Piraee, M.; Alarco, A. M.; Farnet, C. M.; Zazopoulos, E.; J. Antibiot. 2006, 59,533

76. Fulco, P.; Wenzel, R. P.; Expert Rev. Anti. Infect. Ther. 2006, 4, 939.

77. Yamashita, A.; Norton, E.; Petersen, P. J.; Rasmussen, B. A.; Singh, G.; Yang, Y. J.; Mansour, T. S.; Ho, D. M.; Bioorg. Med. Chem. Lett. 2003, 13,3354

78. Watters, A. A.; Jones, R. N.; Leeds, J. A.; Denys, G.; Sader, H. S.; Fritsche, T. R.; J. Antimicrob. Chemother. 2006, 57, 914.

79. He, H.; Appl. Microbiol. Biotechnol. 2005, 67, 444.

80. Brandi, L.; Fabbretti, A.; La Teana, A.; Abbondi, M.; Losi, D.; Donadio, S.; Gualerzi, C. O.; Proc. Natl. Acad. Sci. U. S. A. 2006, 103, 39.

81. Naidu, B. N.; Sorenson, M. E.; Matiskella, J. D.; Li, W. Y.; Sausker, J. B.; Zhang, Y. H.; Connolly, T. P.; Lam, K. S.; Bronson, J. J.; Pucci, M. J.; Yang, H.; Ueda, Y.; Bioorg. Med. Chem. Lett. 2006, 16, 3545.

82. Rittenhouse, S.; Biswas, S.; Broskey, J.; McCloskey, L.; Moore, T.; Vasey, S.; West, J.; Zalacain, M.; Zonis, R.; Payne, D.; Antimicrob. Agents Chemother. 2006, 50, 3882.

83. Johnson, A. P.; Curr. Opin. Investig. D. 2007, 8, 168.

84. Livermore, D. M.; J. Antimicrob. Chemother. 2005, 56, 611; Pankey, G. A.; J. Antimicrob. Chemother. 2005, 56, 470. 